\title{
Diffusion turbulente à travers une discontinuité de densité
}

\author{
PAR H. ROUSE \\ IOWA INSTITUTE OF HYDRAULIC RESEARGH \\ STATE UNIVERSITY OF IOWA, IOWA CITY \\ ET J. DODU \\ LABORATOIRES DE MÉCANIQUE DES FLUIDES \\ ÉCOLE NATIONALE SUPÉRIEURE D'ÉLECTROTECHNIQUE ET D'HYDRAULIQUE DE GRENOBLE \\ English text, p. 530
}

\begin{abstract}
Dans le but de connaître l'influence d'une agitation donnée sur les couches superposées de liquides de densités légèrement différentes, dont on rencontre de nombreux exemples dans la nature: eau pure et eau turbide, eau pure et eau salée, couches fluides de températures différentes, - les auteurs ont entrepris une étude en laboratoire.

Les expériences ont permis de définir une vitesse de diffusion pour le liquide passant d'une couche immobile dans une couche artificiellement agitée. Conformément aux règles de lanalyse dimensionnelle, la valeur de cette vitesse entre dans la formation d'un paramètre. de diffusion, fonction d'un nombre de Froude (caractéristique des effets dus à la gravité) et d'un nombre de Reynolds (caractéristique des effets dus à la viscosité).

Dans le cadre de cette analyse, les auteurs présentent les résultats des séries d'expériences effectuées, en précisant la fonction précédente. En conclusion, ils notent que, contrairement $\dot{a}$ leur attente, ces expériences n'ont pas révélé de limite de stabilité; mais ils insistent sur ce fait important: l'agitation d'une couche fluide n'affecte pratiquement pas la couche voisine de densité peu différente, sauf dans le domaine extrêmement voisin de la surface de séparation, cette surface restant alors constamment caractérisée.
\end{abstract}

La diffusion des fluides à l'intérieur de couches de densités légèrement différentes joue un rôle capital dans divers phénomènes de météorologie, d'hydraulique et d'océanographie. Ces phénomènes comportent d'ordinaire le mouvement relatif d'une couche par rapport à l'autre, tels le mouvement des couches chaudes et froides de l'atmosphère, celui d'un courant chargé de matériaux solides sous l'eau limpide dans un réservoir, celui des couches d'eau pure et d'eau salée superposées dans les estuaires, ou celui des courants thermiques dans les océans. Dans chaque cas, la vitesse de mélange dépend
To the end of understanding the influence of a given agitation on superposed layers of liquid of slightly different density - of which one encounters numerous examples in nature: clear and turbid water, pure and saline water, fluid layers differing in temperature - the authors undertook a laboratory study of the phenomenon.

Their experiments have permitted the definition of a velocity of diffusion for the liquid passing from an immobile layer into a layer that is artificially agitated. In conformance with the laws of dimensional analysis, the magnitude of that velocity enters into the formation of $a$ diffusion parameter, wich in turn is a function of a Froude number (characteristic of gravitational effects) and of a Reynolds number (characteristic of viscous effects).

In the course of the following analysis, the authors present the results of the series of experimental measurements which they made to determine the foregoing function.

They conclude that, contrary to expectation, the experiments revealed no limit of stability; however, they disclosed one important fact: the agitation of a fluid layer has no effect upon a neighboring layer of slightly different density except in the immediate vicinity of the interface between them, that interface remaining continuously defined.

d'une fonction, jusqu'à présent inconnue, des nombres de Froude et de Reynolds caractérisant le mouvement relatif. Aux faibles valeurs de ces paramètres, les influences stabilisatrices de la gravité et de la viscosité doivent certainement être suffisantes pour empêcher la destruction de l'interface, et, à partir de résultats expérimentaux assez restreints, on a proposé une courbe frontière entre les régions des régimes stable et instable; cette courbe est représentée par la figure $1[1]$. Puisqu'elle correspond aussi à un régime de mélange constant (c'est-à-dire nul), on peut s'attendre à ce que les courbes qui corres- 


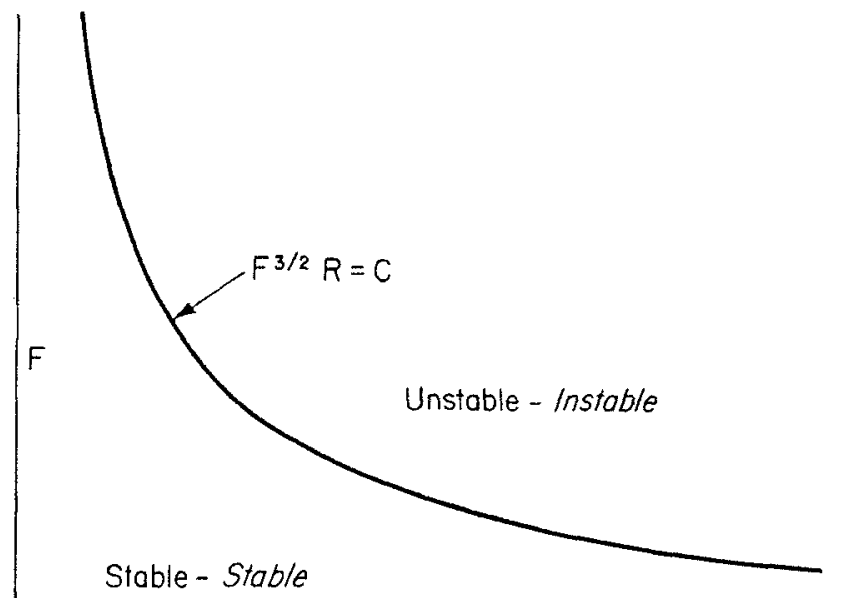

\section{$\mathrm{R}$}

Fig. 1

Stabilité de l'interface entre deux couches de masses spécifiques différentes en mourement. Stability of the interface between moving strata of different densities.

pondent aux régimes des mélanges coustants mais finis, pour les valeurs élevées des nombres de Froude et de Reynolds, aient des formes telles qu'elles représenteront des fonctions analogues. Néanmoins, aucune méthode générale n'a été établie jusqu'à présent pour prévoir l'apparition de l'instabilité, encore moins la rapidité de la diffusion consécutive.

Ơn rencontre un phénomène étroitement lié à cette question - quoique plus simple, à cause de l'absence de mouvement relatif entre les couches - dans la modification des niveaux d'égale température dans les océans, pendant les tempêtes. On sait que dans certains cas, la turbulence, engendrée probablement par l'agitation de la surface sous l'effet des vagues, donne naissance à une diffusion entre les couches thermiques à une certaine distance au-dessous de cette surface. Cependant on dispose de peu de renseignements soit sur les conditions de stabilité, soit sur l'effet du processus de la diffusion sur les isothermes; d'après certains, le gradient local de température deviendrait de plus en plus marqué; d'après d'autres, il se formerait une couche-tampon intermédiaire.

Dans l'idée qu'une étude en laboratoire de ce phénomène plus simple verserait quelque lumière sur celui qui comporte un mouvement relatif, le premier auteur a jeté les bases des expériences appropriées pendant l'année qu'il a passée à Grenoble, France, comme Fulbright Research Scholar; ces expériences ont été menées par le second auteur, aux Laboratoires de Mécanique des Fluides de l'Ecole Nationale Supérieure d'Electrotechnique et d'Hydraulique, avec le ma- tériel prêté dans ce but par les Etablissements Neyrpic. L'appareil comprenait essentiellement deux cylindres fermés, en plexiglas, de $20 \mathrm{~cm}$ de diamètre et de $50 \mathrm{~cm}$ de hauteur, et au-dessus d'eux un mécanisme de commande différentiel donnant la gamme des rréquences de 0 à $15 \mathrm{c} / \mathrm{s}$. Pour la présente étude, l'un des deux cylindres était équipé d'un agitateur (fig. 2) : c'était une grille unique à maille carrée, faite de bandes mé-
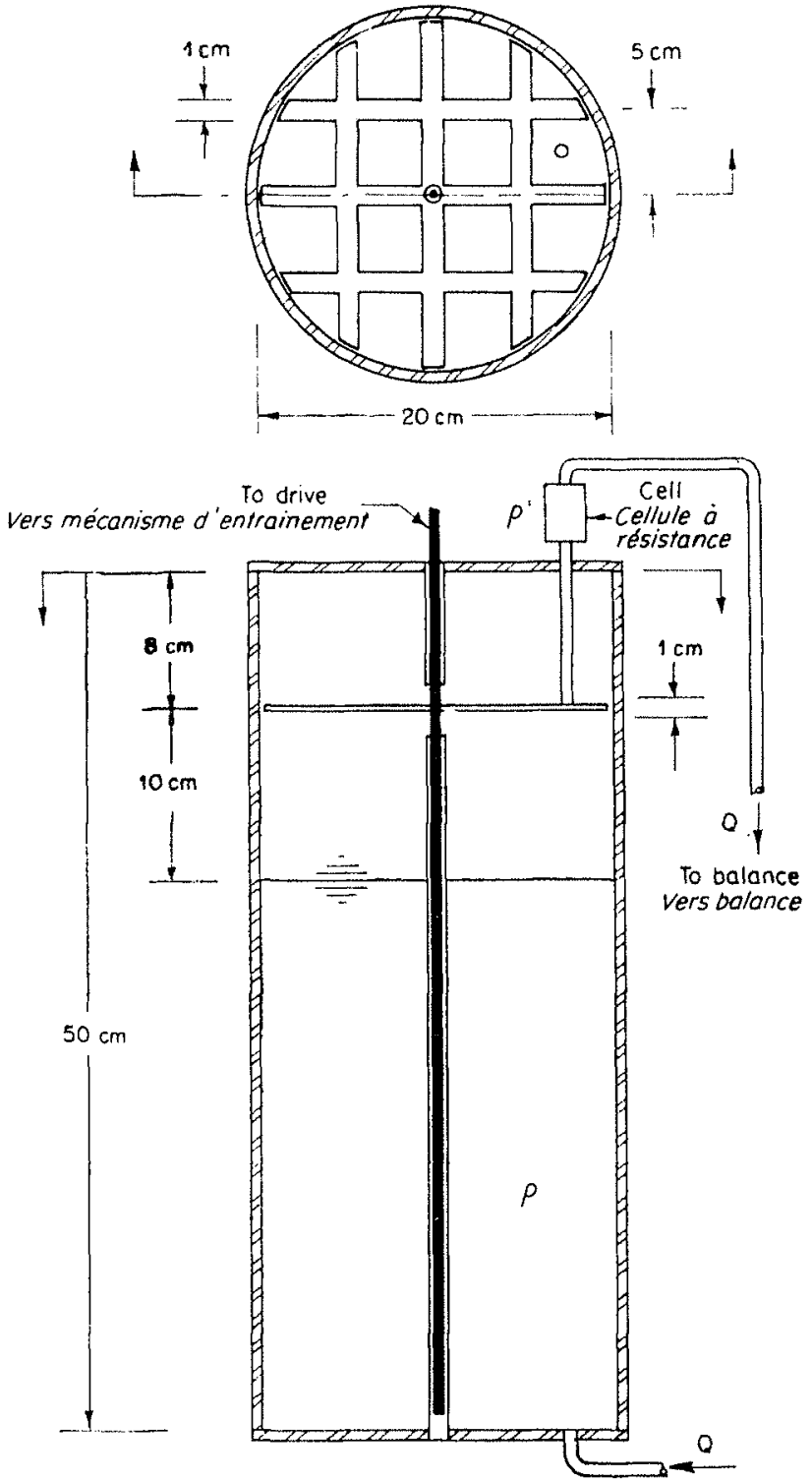

Fig. 2

Schéma de l'appareil experimental Arrangement of the experimental equipment

talliques de $1 \mathrm{~cm}$ de largeur, de $5 \mathrm{~cm}$ d'entreaxe et située dans un plan horizontal; un dispositif à excentrique, à amplitude variable, donnait à la grille un mouvement d'oscillation vertical, dans la gamme des fréquences disponibles. On pouvait remplir le cylindre d'eau pure et d'eau 
salée (l'une des couches ou les deux étaient colorées), on mettait en mouvement l'agitateur à une certaine distance au-dessus de l'interface qui les séparait, et on observait la diffusion qui en résultait.

Des expériences préliminaires révélèrent que la turbulence produite dans la couche supérieure par le mouvement de la grille, au lieu de pénétrer assez loin dans la couche inférieure pour former une zone-tampon comme on l'avait prévu, n'y pénétrait pas du tout - mais qu'elle produisait plutôt à l'interface des crêtes irrégulières dont les prolongements s'élevaient et se diffusaient rapidement à travers la couche supérieure. Toutes les fois que l'on arrêtait le mécanisme de l'agitateur, la tranquillisation des crêtes les plus récemment développées tendait à former une couche intermédiaire de masse spécifique variable, semblable à celle qu'on observe parfois dans les océans. Mais, aussi longtemps que le dispositif continuait à fonctionner, l'interface devait descendre graduellement, alors que la concentration de la couche supérieure augmentait continuellement, la couche inférieure restant par ailleurs immobile.

Comme on supposait que l'intensité de la turbulence diminuait avec la distance de l'agitateur, on a pensé que les mesures de la vitesse de diffusion n'auraient de sens que si la distance moyenne entre l'agitateur et l'interface était maintenue constante. On employa done un procédé qui consistait à introduire du liquide inférieur, et à extraire du liquide supérieur, au débit convenable pour maintenir l'interface à un niveau donné. On pouvait alors mesurer continuellement la masse spécifique du liquide sortant, dont la salinité croissait, en lui faisant traverser une petite cellule à résistance, et on pouvait déterminer l'importance de la diffusion - indiqué dans ce cas par la valeur du débit de sortie $Q-$ en pesant le volume du liquide collecté pendant les intervalles de temps successifs.

$\triangle \rho\left(\mathrm{gr} / \mathrm{cm}^{3}\right)$

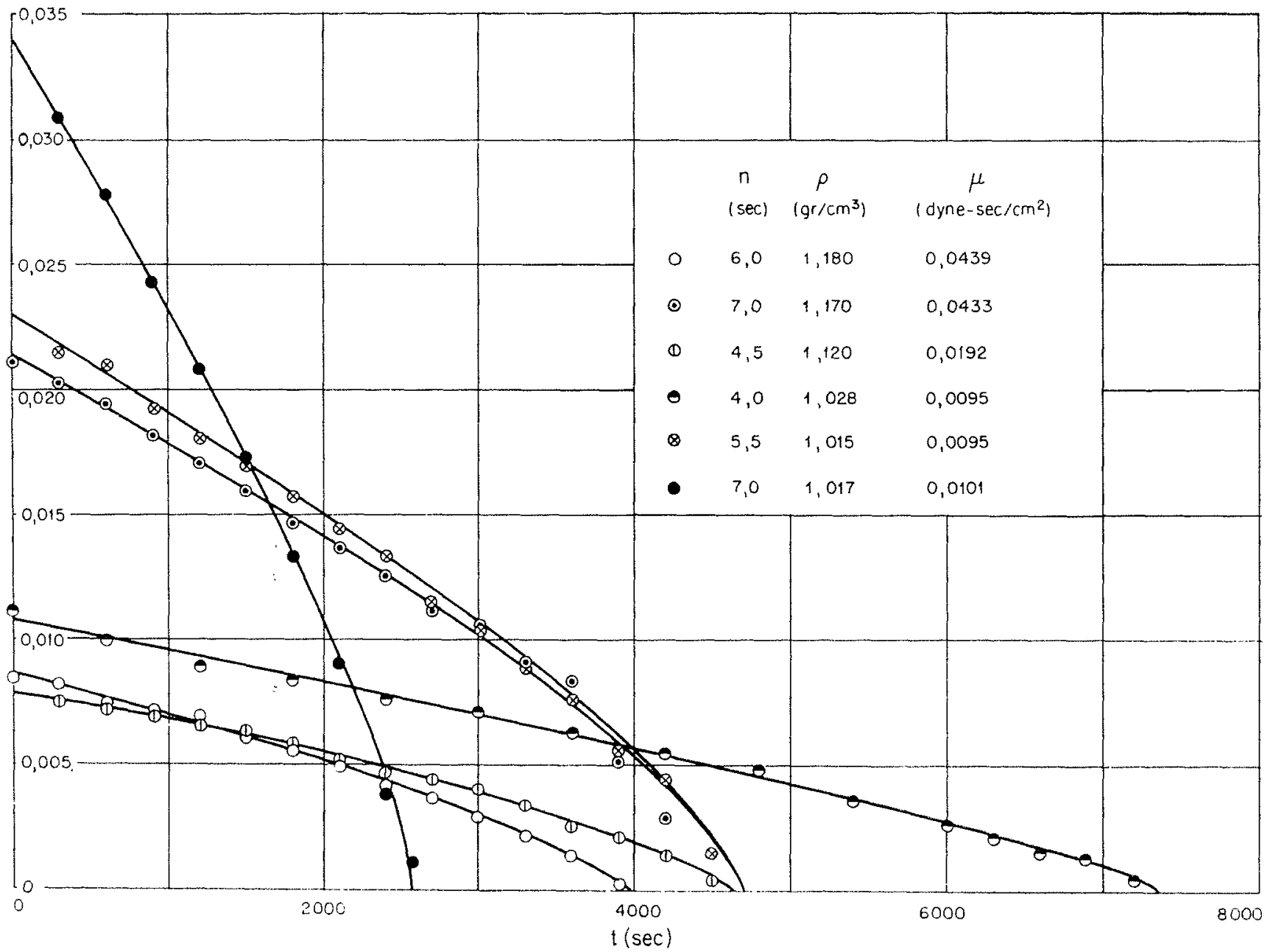

F1G. 3

Variation de l'écart de masse spécifique en fonction du temps.

Variation of the density difference with time. 


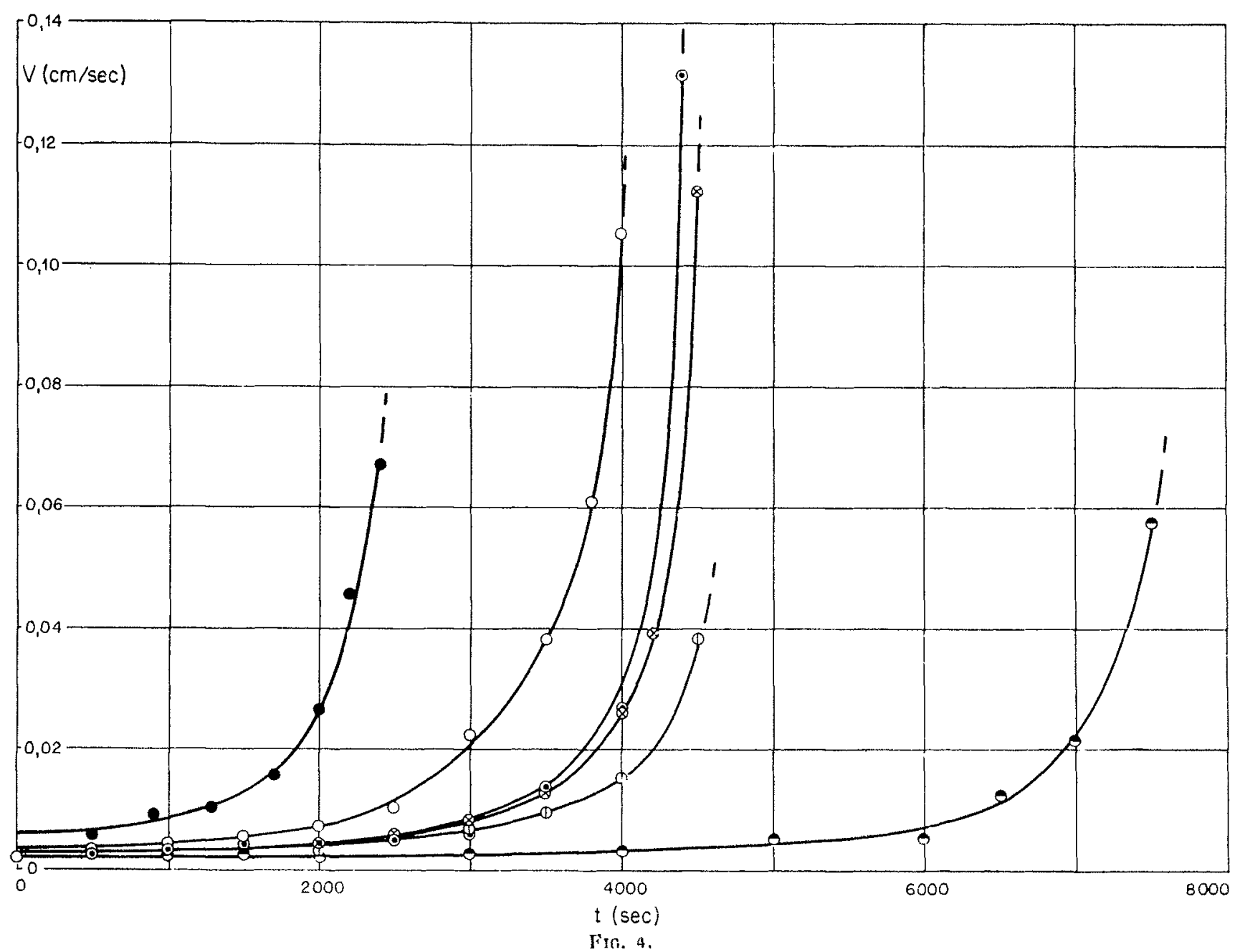

Variation de la vitesse de diffusion en fonction du temps.

Variation of the diffusion rate with time

Les couches de masses spécifiques et de viscosités voulues étaient aisément préparées par dissolution des quantités convenables de sel et de sucre dans l'eau. On a éliminé l'effet du changement de position et d'amplitude de l'agitateur, qui n'a qu'une influence indirecte sur le phénomène étudié, en plaçant arbitrairement l'agitateur (et l'extrémité du tube de prise) à $8 \mathrm{~cm}$ audessous du sommet du cylindre, en maintenant l'interface à $10 \mathrm{~cm}$ au-dessous de l'agitateur et en conservant l'amplitude constante de $1 \mathrm{~cm}$ pour l'agitateur. La seule longueur $h=18 \mathrm{~cm}$ égale à l'épaisseur de la couche supérieure suffisait à caractériser l'échelle du système. On avait alors à déterminer les relations qui existent entre d'une part, $a$ ) la différence $\Delta_{\imath}=\rho-\rho^{\prime}$ des masses spécifiques mesurées des liquides, ou $b$ ) la vitesse de mélange $v=Q / A$, et, d'autre part, la fréquence $n$, la masse spécifique de référence $\rho$, la viscosité $\mu$, l'accélération de la pesanteur $g$, et le temps d'observation $t$ :

$$
\Delta \rho, v=f_{1,2}(h, n, \varphi, \mu, g, t)
$$

Six séries de mesures soigneusement contrôlées, avec différentes masses spécifiques, viscosités et fréquences d'agitateur ont été exécutées pour déterminer ces fonctions. Les figures 3 et 4 indiquent la variation de $\Delta$ ? et de $v$ en fonction du temps pour des valeurs constantes de $h, n, \rho, \mu$, et $g$; dans chaque cas, $v$ et la vitesse de variation de $\Delta \rho$ avaient des valeurs finies au début et s'accroissaient ensuite d'une manière permanente, la grandeur de $v$ et la pente de la courbe de $\Delta_{0}$ devenant éventuellement indéterminées lorsque $\Delta \rho$ approchait de la limite zéro. On remarquera que le contrôle du niveau de l'interface à ce moment devenait de plus en plus difficile, car l'agitation à la surface semblait croître finalement sans limite.

Comme les expériences ont montré que chacune des deux fonctions de diffusion variait continuellement jusqu'à ce que cette limite soit atteinte, il apparut convennble, dans une analyse ultérieure des résultats, de remplacer le temps absolu $t$ par la différence entre 
ce temps et sa valeur finale $t_{0}$, bien que cette dernière soit souvent mal définie. En outre, comme les valeurs des deux masses spécifiques étaient telles, au cours des expériences, que $\Delta \rho$ n'excédait jamais $3 \%$ de $\rho$, l'effet d'inertie était essentiellement indépendant de la variation de $\rho^{\prime} ; \Delta \rho$ et $g$ pouvaient donc être combinés en la seule quantité $\Delta \%=g \Delta \rho$. Finalement, pour utiliser la fréquence de l'agitateur et l'échelle comme une mesure plus générale de la turbulence, on a supposé que le coefficient de mélange $\varepsilon$ au voisinage de l'interface était proportionnel à la variable $n$ et au carré de la valeur constante $h$, c'est-à-dire : $\varepsilon=C=C h h^{2}$; à défaut de meilleurs renseignements, on a estimé l'ordre de grandeur du coefficient de proportionnalité $\left(\mathrm{C} \approx 2,5 \times 10^{-4}\right)$, à partir des résultats connus sur la turbulence à l'aval d'une grille [2] pour une vitesse d'écou-

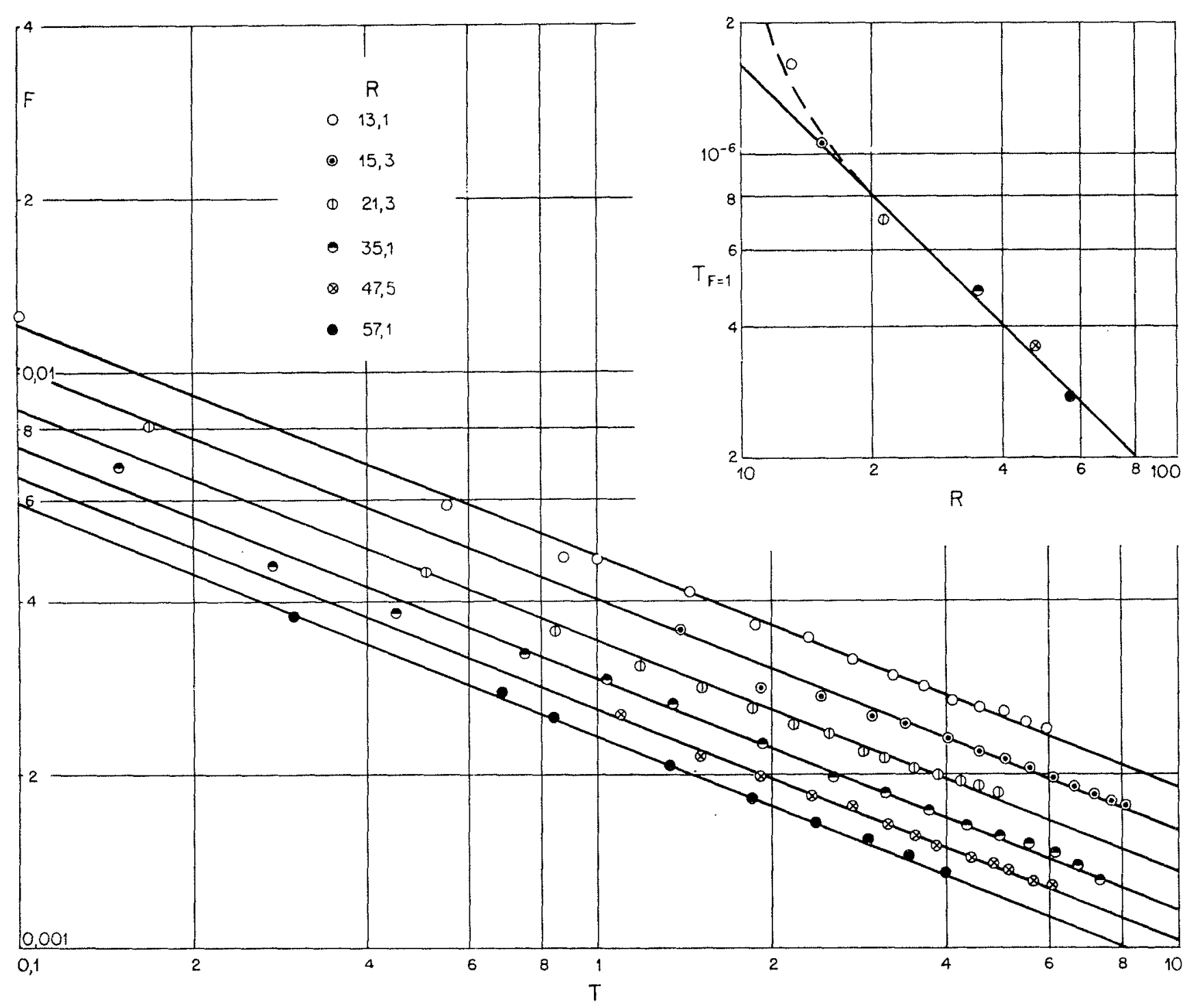

Fí. 5

Variation du nombre de Froude

en fonction du parametre de temps et du nombre de Reynolds.

The Froude number as a function of the time parameter and the Reynolds number.

lement égale à la vitesse moyenne relative de l'agitateur.

Grâce à ces modifications, les variables indépendantes dans les fonctions précédentes se réduisaient aux suivantes :

$$
\Delta \gamma, v=f_{3,4}\left(h, \varepsilon, \varphi, !, t_{0}-t\right)
$$

Conformément au théorème des $\Pi$ de l'analyse dimensionnelle, on peut combiner ces variables en quatre groupes sans dimension - un nombre de Froude, un paramètre de diffusion, un nombre de Reynolds et un paramètre de temps :

$$
\begin{gathered}
\mathrm{F}=\frac{\varepsilon}{\sqrt{h^{3} \Delta \gamma / \rho}} \quad \mathrm{V}=\frac{v h}{\varepsilon} \quad \mathrm{R}=\frac{\varepsilon}{\mu / \rho} \\
\mathrm{T}=\frac{\left(t_{0}-t\right) \varepsilon}{h^{2}}
\end{gathered}
$$


Ces groupes sont liés par les fonctions :

$$
\begin{aligned}
& \vartheta_{1}(F, R, T)=0 \\
& \varphi_{2}(V, R, T)=0
\end{aligned}
$$

Par élimination du paramètre de temps $\mathrm{T}$, ces deux fonctions deviennnent simplement:

$$
\varphi_{3}(\mathrm{~V}, \mathrm{~F}, \mathrm{R})=0
$$

Une représentation logarithmique des séries de mesures de masses spécifiques de la figure 3 donnant $F$ en fonction de $T$ et du parametre $R$, conformément à l'équation (1), est donnée par la figure 5. Malgré la dispersion expérimentale, on peut tracer des lignes moyennes correspondant à $R$ constant avec une pente commune de $-2 / 5$. En outre, le calcul de l'intersection de ces lignes avec la droite $F=1$ (graphique auxiliaire) fournit en première approximation $\mathrm{T}_{\mathrm{F}=1}=1,6 / 10^{5} \mathrm{R}$. L'équation (1) prend alor's la forme explicite :

$$
\mathrm{F}^{5 / 2} \mathrm{RT}=1,6 \times 10^{-5}
$$

La figure 6 représente un graphique semblable, basé sur les résultats de la diffusion portés sur la figure 4 , conformément à l'équation (2), le paramètre de diffusion $\mathrm{V}=v h / \varepsilon$ remplaçant maintenant le nombre de Froude $F$. Contrairement à ce qu'on voit sur la figure 5, la dispersion expérimentale est plus prononcée, mais on n'observe aucune déviation systématique en fonction de R. En fait, on peut utiliser les deux séries de résultats expérimentaux pour montrer que $R$ n'est pas un facteur principal dans l'ëquation (2). Quoique calculées indépendamment, les fonctions de poids spécifique et de diffusion sont di-

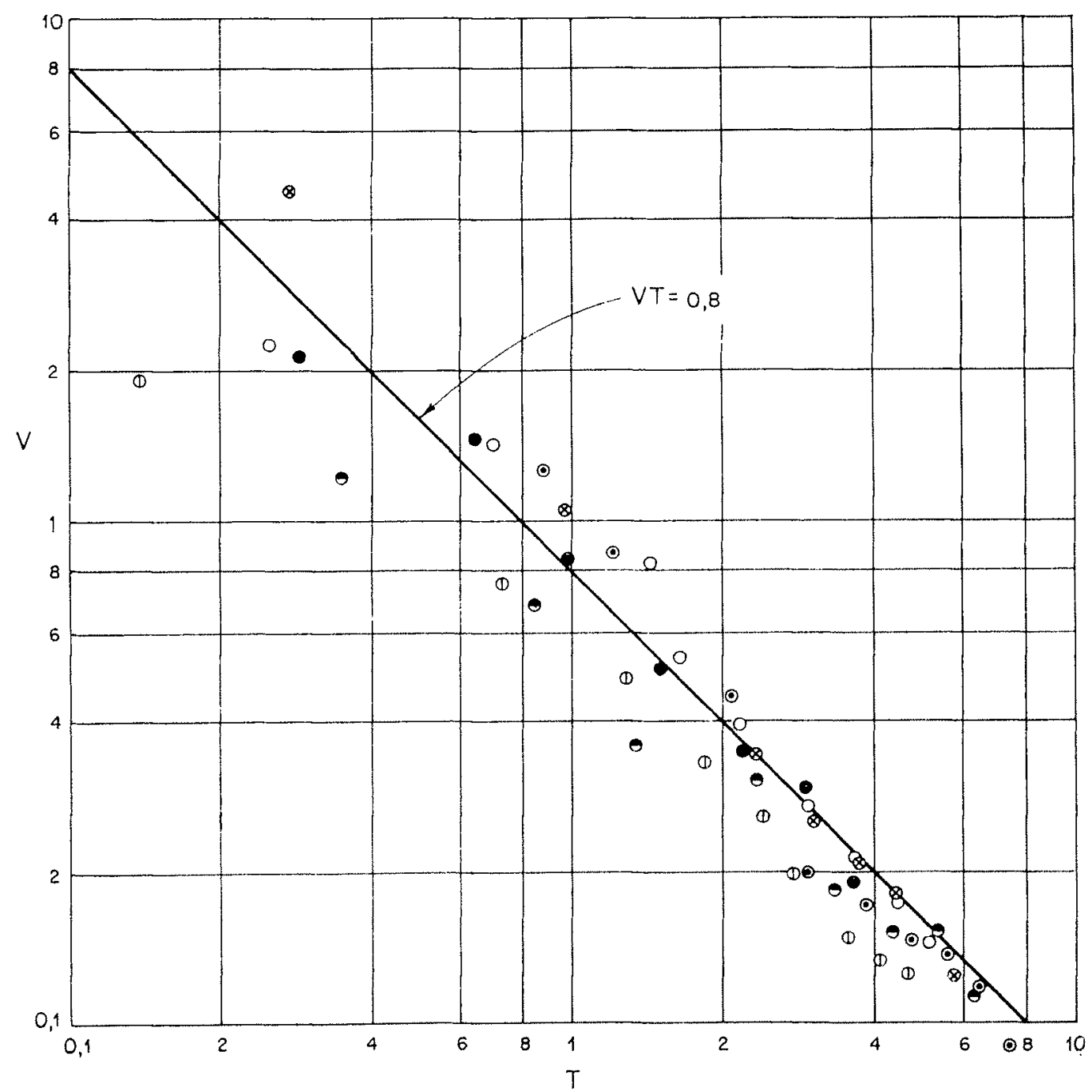

Fig. 6

Variation du paramètre de diffusion en fonction du paramètre de temps.

The diffusion parameter as a function of the time parameter, 
rectement liées, puisque par raison de continuité :

$$
\mathrm{V} \Delta \gamma d t=-h d(\Delta \gamma)
$$

d'où :

$$
\mathrm{V}=-\frac{2}{\mathrm{~F}} \frac{d \mathrm{~F}}{d t}
$$

Cela permet de mettre l'éçuation (4) sous la forme de l'équation (2),

$$
\mathrm{V} \mathrm{T}=0,8
$$

qui est représentée par la droite unique figurant sur le graphique de la figure 6. La simplicité plutôt surprenante de l'équation (5) n'indique pas que $V$ ne dépende pas de $F$ ni de $R$, mais simplement que toute variation de $\mathrm{V}$ produite par la variation de $F$ ou de $R$ est contrebalancée par une variation réciproque de $T$.

La dispersion expérimentale observable sur la figure 6, d'une part, et la discordance partielle entre les mesures de diffusion (représentées par les points) et les mesures de masses spécifiques (représentées par la droite), d'autre part, appellent un commentaire. Malgré le retard réel de l'appareil de mesure, on peut considérer que les mesures de masses spécifiques sont plus sûres que les mesures de diffusion, car le débit de sortie était déterminé par l'aug- mentation du volume collecté pendant des intervalles de temps finis, et par conséquent - contrairement aux mesures de masses spécifiques - sa détermination était fortement influencée par les petites erreurs inévitables dans le contrôle du niveau de l'interface; cela se vérifie particulièrement vers la fin d'une expérience, et la valeur de $t_{0}$ utilisée dans le calcul de la diffusion est celle de la figure 3 , mieux déterminée que celle de la figure 4. Cependant, il existe une autre source de divergence dans la distribution de la masse spécifique elle-même. Ơn ne pouvait pas déceler des variations de masse spécifique instantanées en fonction de la hauteur dans la couche supérieure, au moyen de la cellule à résistance, de réponse assez lente, qui était utilisée pour les mesures; pourtant, il devait exister un gradient pour entretenir la diffusion du liquide au-delà de l'interface qu'il avait traversée. Bien que la position de l'orifice de sortie au niveau moyen de l'agitateur tende à donner en première approximation la masse spécifique moyenne de la couche, le fait que le point de masse spécifique moyenne exacte se situait toujours un peu plus bas devait rendre la vitesse de diffusion, calculée à partir des mesures de masse spécifique, légèrement plus grande que celle qu'on mesurait réellement.

Dans ces conditions, on peut conclure que les équations (4) et (5) correspondent l'une et l'au-

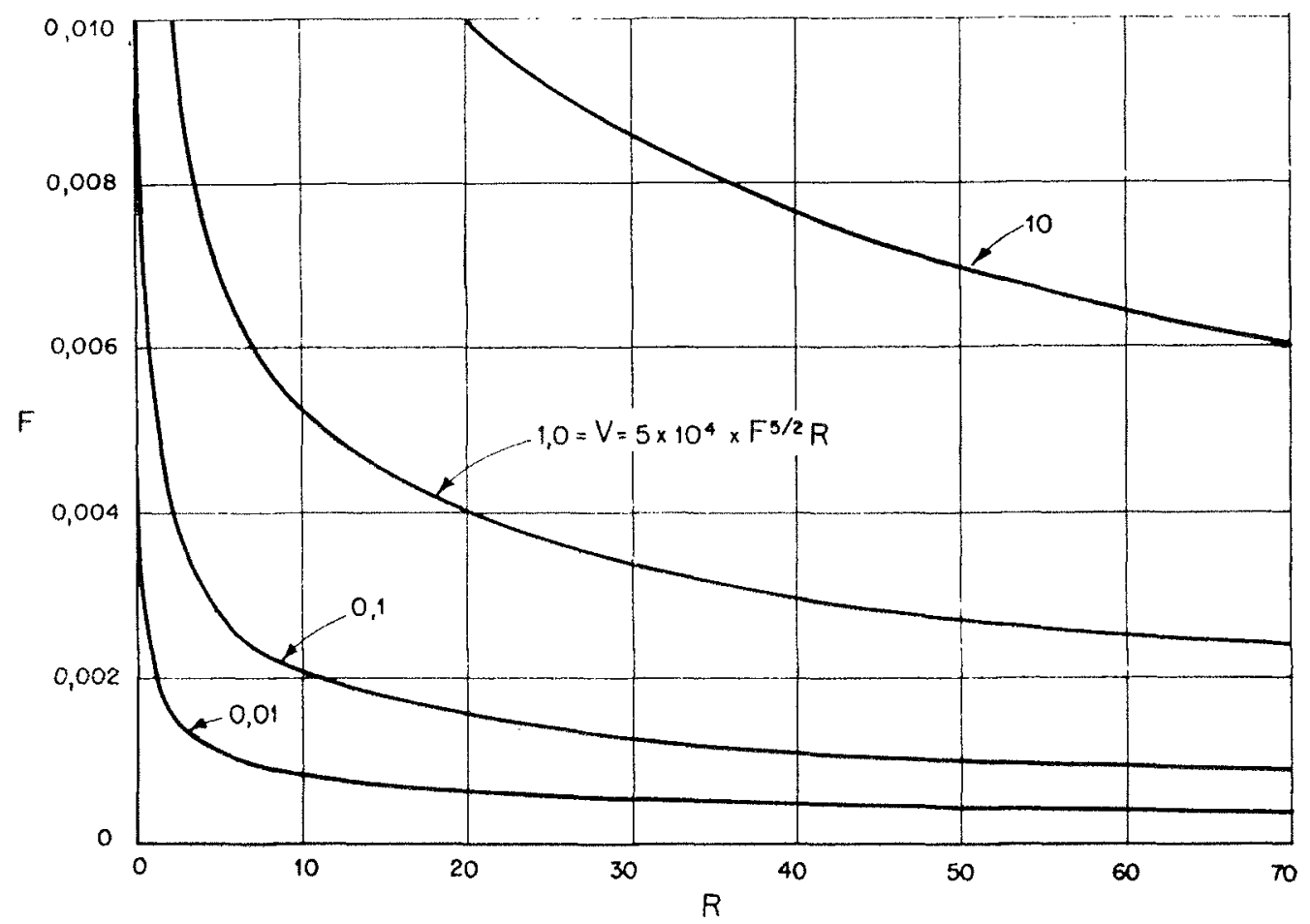

Fig. 7

Représentation générale de la fonction de diffusion.

Generalized plot of the diffusion function. 
tre au phénomène considéré avec une approximation raisonnable. A partir de ces deux équations, on pourra obtenir alors la fonction la plus intėressante représentée par l'équation (3), en éliminant la quantité $\mathrm{T}$; le résultat de cette élimination est :

$$
\frac{\mathrm{V}}{\mathrm{F}^{5 / 2} \mathrm{R}}=5 \times 10^{4}
$$

Pour permettre une comparaison avec la figure 1 , la figure 7 représente la variation de $F$ en fonction de $R$, et de $V$ comme paramètre, conformément à l'équation (6). D'abord, il est évident que, comme on l'a supposé précédemment, les courbes de diffusion relative constante correspondent toutes à des fonctions analogues de $\mathrm{F}$ et de R. Mais, tandis que la seule courbe de diffusion constante représentée par la figure 1 est celle qui concerne la valeur limite zéro, c'est précisément cette limite qui n'existe pas sur la figure 7; et il y a une différence appréciable pour la puissance qui entre dans la relation, entre la valeur $3 / 2$ indiquée précédemment et la valeur $5 / 2$ actuellement trouvée.

En ce qui concerne cette dernière divergence, un raisonnement simple ne peut justifier jusqu'à présent qu'une puissance comprise entre les deux précédentes. II utilise l'hypothèse selon laquelle l'accroissement de l'énergie potentielle par unité de volume, $v \Delta \gamma$, est proportionnelle à la production d'énergie turbulente par l'agitaleur, $\rho n^{3}$, et conduit à la relation $V \sim F^{2}$. (On ne peut introduire l'influence de la viscosité que par une hypothèse encore plus arbitraire.)

Quant à la première divergence, si les expériences indiquaient qu'un régime de mélange fini arrive à s'imposer quelles que soient les valeurs des nombres de Froude et de Reynolds, elles se trouveraient en contradiction avec l'analyse précédente aussi bien qu'avec le simple bon sens luimême si l'on ne faisait une remarque particulièrement importante. Dans les expériences actuelles, les conditions de la turbulence étaient imposées d'une manière indépendante au-dessus de l'interface, tandis que dans le cas d'un mouvement relatif, elles varient avec l'intensité de la tension tangentielle entre les couches. Il y a pourtant une Jégère restriction à la généralité de cette conclusion : le déplacement du point qui correspond au nombre de Reynolds le plus fai- ble, figuré sur le graphique auxiliaire de la figure 5 , montre que la fonction peut tendre vers une limite, conformément à la courbe pointillée, au lieu de continuer à varier indéfiniment selon la droite qui sert de base à l'équation (4). Bien que l'existence d'une telle limite semble logique, on se rendra compte qu'on a rencontré une influence non désirée de la viscosité qui se faisait sentir avec une intensité variable au cours des expériences; il s'agit de la diminution de la turbulence en fonction de la distance de l'agitateur, dont la conséquence est que le coefficient de mélange au niveau de l'interface ne varie pas nécessairement en fonction de la fréquence seulement, comme on l'a supposé. En tenant compte de cette influence, on justifierait simplement la conclusion selon laquelle les résultats expérimentaux n'ont pas indiqué la limite correspondant à la vitesse de mélange nulle.

Quelles qu'aient été leurs imperfections, les expériences décrites ici ont permis de découvrir deux faits importants. D'abord, la turbulence engendrée dans l'une des couches de deux liquides superposés, auparavant immobiles, ne pénètre pas dans la seconde couche; elle ne produit pas non plus une couche-tampon entre les deux; le liquide est plutôt entraîné à partir de la surface de la couche non turbulente et diffusé à travers la zone turbulente. Ensuite, aussi longtemps qu'un mécanisme externe quelconque produit une turbulence, on ne peut pas espérer observer une limite de stabilité pour les petites différences de densité, analogue à celle qui caractérise le mouvement tangentiel de deux conches de part et d'autre de leur interface; au contraire, il semble qu'il existe une valeur finie de la diffusion à travers l'interface pour toute valeur du nombre de Froude ou du nombre de Reynolds. En outre, bien que les relations déduites des résultats expérimentaux dépendent quantitativement de la géométrie propre de l'appareil, leurs formes doivent néanmoins indiquer les rôles respectifs que jouent les nombres de Froude et de Reynolds, quelles que soient les dimensions des limites géométriques.

\section{RÉFÉRENCES}

[1] Engineering Hydraulies, édité par Rouse, New-York, 1950, p. 762 .

[2] Engineering Hydraulics, p. 92. 


\section{Turbulent diffusion across a density discontinuity}

For illustrations, see French text, p. 522

Diffusion of fluid between strata of slightly different densities plays a critical role in various phenomena of meteorology, hydraulics, and oceanography. These usually involve the motion of one stratum relative to another, such as that of warm or cold layers in the atmosphere, a sediment-laden current beneath the clear water of a reservoir, superposed fresh and salt water in estuaries, and thermal streams in the ocean. In each instance the rate of intermixing depends upon an as-yet-unknown function of Froude and Reynolds numbers characterizing the relative motion. At low values of these parameters, to be sure, the stabilizing influence of gravity and viscosity should be sufficient to prevent disruption of the interface, and from rather limited experimental data it has been assumed that the border line between stable and unstable regimes is such as shown in fig. 1 [1]. Since this is also a curve of constant (i.e., zero) mixing curves of constant but finite mixing at higher Froude and Reynolds numbers might be expected to be of similar functional form. Nevertheless, no general method has as yet been established for predicting even the onset of instability, much less the subsequent diffusion rate.

A closely related phenomenon - somewhat simpler, because relative motion between the layers is not involved-is found in the modification of the oceanic thermocline during a storm. Turbulence presumably generated by the breaking of surface waves is, under certain circumstances, known to produce diffusion between thermal layers some distance below. However, little information is at hand about either the requirements of stability or the effect of the diffusion process upon the thermocline, some contending that the local temperature gradient becomes more pronounced and others that an intermediate buffer layer is formed.

In the belief that a laboratory study of this simpler occurrence might also throw some light on that involving relative motion, the senior author initiated such experiments during his year as Fulbright Research Scholar at Grenoble, France. These were carried out by the junior author in the Fluid Mechanics Laboratory of the Ecole Nationale Supérieule d'Electrotechnique et d'Hydraulique with equipment loaned for the purpose by the Etablissements Neyrpic. The apparatus consisted, in brief, of two closed plastic cylinders $20 \mathrm{~cm}$ in diameter and $50 \mathrm{~cm}$ high, above which was a motor-driven differential mechanism having a speed variation from 0 to
15 rps. For the present study, one of the cylinders was equipped with an agitator (see fig. 2 ) in the form of a single square-meshed lattice of 1-cm metal strips $5 \mathrm{~cm}$ on center in a horizontal plane; an eccentric device of variable amplitude permitted the grid to be oscillated vertically in simple harmonic motion through the available frequency range. The cylinder could thus be filled with fresh and saline water (one or both layers being colored with dye), the agitator set into motion some distance above the interface between them, and the resulting diffusion observed.

Preliminary tests revealed that the turbulence produced in the upper stratum by the motion of the grid, instead of penetrating far enough into the lower stratum to form a buffer zone as anticipated, did not penetrate at all-rather, it produced irregular interfacial cusps from which streamers were rapidly lifted and diffused through the upper stratum. Whenever the agitator mechanism was stopped, to be sure, the settling of the most recently developed streamers tended to form an intermediate layer of variable density similar to that sometimes observed in the ocean. But as long as the device conlinued to operate, the interface would gradually fall as the concentration of the upper layer increased, the lower layer otherwise remaining undisturbed.

Since the intensity of the turbulence was presumed to diminish with distance from the agitator, it was decided that measurements of the diffusion rate would be significant only if the average distance between agitator and interface were held constant. Means were therefore provided of replenishing the lower fluid and removing the upper fluid at the rate necessary to maintain the interface at a predetermined level. The density of the increasingly saline effluent could then be measured continuously by passing it through a small resistance cell, and the rate of diffusion-indicated under these circumstances by the rate of efflux $Q$-could be determined by weighing the efflucnt collected during successive intervals of time.

Layers of any desired density and viscosity were readily preparable by the proper admixture of salt and sugar to water. The effect of changes in the position and amplitude of the agitator, which had only indirect bearing upon the phenomenon under study, was eliminated by arbitrarily placing the agitator (and the tip of the withdrawal tube) $8 \mathrm{~cm}$ below the top of the 
cylinder, maintaining the interface $10 \mathrm{~cm}$ below the agitator, and adhering to a constant agitator amplitude of $1 \mathrm{~cm}$. The single length $h=18 \mathrm{~cm}$, equal to the thickness of the upper stratum, thus sufficed to designate the scale of the system. The relationships to be determined were then $(a)$ the difference $\Delta \rho=\rho-\rho^{\prime}$ between the measured densities of the fluids, and $(b)$ the derived mixing rate $v=\mathrm{Q} / \mathrm{A}$, each as a function of the frequency $n$ the reference density $\rho$, the viscosity $\mu$, the gravitational acceleration $g$, and the time of observation $t$ :

$$
\Delta \rho, v=f_{1,2}(h, n, \rho, ! ., g, t)
$$

Six carefully controlled runs with different densities, viscosities, and agitator frequencies were then made to determine these functions. For constant values of $h, n, \rho, \mu$, and $g, \Delta \rho$ and $v$ were fund to change with $t$ as indicated in figs. 3 and 4. In every instance both $v$ and the rate of change of $\Delta \rho$ had finite magnitudes at the outset and thereafter increased steadily, the magnitude of $v$ and the slope of the $\Delta \rho$ curve eventually becoming indeterminate as $\Delta ?$ approached the limit zero. Control of the interfacial level, it should be remarked, thereby became increasingly difficult, for the surface disturbances finally seemed to grow without limit.

Since the tests thus indicated that each of the two diffusion functions changes continuously until this limit is reached, it appeared advisable in the further analysis of the results to replace the absolute time $t$ by the difference between it and its terminal value $t_{0}$, ill-defined as the latter often was. Moreover, because the experimental values of the two densities were such that $\Delta$ ? was never greater than $3 \%$ of $\rho$, inertial effects were essentially independent of changes in $\rho^{\prime}$; $\Delta \rho$ and $g$ could hence be combined into the single quastity $\Delta y=g \Delta \rho$. Finally, to convert the agitator frequency and scale into a more general measure of the turbulence, the mixing coefficient $\varepsilon$ in the vicinity of the interface was assumed proportional to the variable $n$ and the square of the constant $h$-i.e., $\varepsilon=\mathrm{C} n h^{2}$; for want of better information, the order of magnitude of the coefficient of proportionality

$$
\left(\mathrm{C} \approx 2.5 \times 10^{-4}\right)
$$

was estimated from data on the turbulence downstream from a lattice screen [2] for a velocity of flow equal to the mean relative speed of the agitator.

Through these modifications, the pertinent variables in the foregoing functions were reduced to the following :

$$
\Delta \gamma, v=f_{3,4}\left(h, \varepsilon, \rho, u, t_{0}-t\right)
$$

By means of the II-theorem of dimensional analysis, these variables may be combined into four dimensionless groups-a Froude number, a diffusion parameter, a Reynolds number, and a time parameter :

$$
\begin{gathered}
\mathrm{F}=\frac{\varepsilon}{\sqrt{h^{3} \Delta y / \varphi}} \quad \mathrm{V}=\frac{v h}{\varepsilon} \quad \mathrm{R}=\frac{\varepsilon}{\mu / \rho} \\
\mathrm{T}=\frac{\left(t_{0}-t\right) \varepsilon}{h^{2}}
\end{gathered}
$$

These are related through the functions

$$
\begin{aligned}
& \varphi_{1}(\mathrm{~F}, \mathrm{R}, \mathrm{T})=0 \\
& \varphi_{2}(\mathrm{~V}, \mathrm{R}, \mathrm{T})=0
\end{aligned}
$$

Upon elimination of the time parameter $T$, the two functions become simply

$$
\varphi_{3}(V, F, R)=0
$$

A plot to logarithmic scale of the serjes of density measurements from fig. 3 in the form $F$ versus $T$ with $R$ as parameter, in accordance with eq. (1), is shown in fig. 5. Despite experimental scatter, mean lines of constant $R$ can readily be drawn with the common slope $-2 / 5$. Moreover, evaluation of their intercepts with the line $F=1$ (note the supplementary plot) yields as a first approximation $T_{F=1}=1.6 / 10^{\circ} \mathrm{R}$. Equation (1) hence takes the explicit form

$$
\mathrm{F}^{5 / 2} \mathrm{R} \mathrm{T}=1.6 \times 10^{-5}
$$

A similar plot based on the diffusion data of fig. 4 according to eq. (2) is shown in fig. 6, the diffusion parameter $\mathrm{V}=v h / \varepsilon$ now replacing the Froude number F. Contrary to fig. 5, the experimental scatter is quite pronounced, but no systemmatic trend with $R$ is apparent. As a matter of fact, either set of data may be used to show that $R$ is not a primary factor in eq. (2). Though independently measured, the density and diffusion functions are directly rclated, since, for reasons of continuity,

$$
V \Delta_{\gamma} d t=-h d(\Delta \gamma)
$$

whence

$$
\mathrm{V}=-\frac{2}{\mathrm{~F}} \frac{d \mathrm{~F}}{d t}
$$

This fact permits the conversion of eq. (4) into the functional form of eq. (2),

$$
\mathrm{V} \mathrm{T}=0.8
$$

which is represented by the single line plotted in fig. 6. The rather surprising simplicity of eq. (5) actually does not indicate a lack of dependence of $V$ upon $F$ and $R$, but merely the fact that any change in $V$ produced by variation of $F$ or $R$ 
is counterbalanced by a reciprocal change in $\mathrm{T}$. Both the experimental scatter in fig. 6 and the incomplete agreement between the diffusion measurements (represented by the points) and the density measurements (represented by the line) warrant further comment. Despite the effective lag of the indicator, the density data are considered more dependable than the diffusion data, because the efflux rate was determined from incremental volumes collected in finite intervals of time and hence--unlike the density indication-was very sensitive to slight errors in the control of the interfacial level; this was particularly true toward the end of a run, and the values of $t_{0}$ used in the diffusion computations were the more consistent ones of fig. 3 rather than those of fig. 4 . However, another source of discrepancy lay in the density distribution itself. No instantaneous variation in density with elevation could be detected in the upper stratum with the rather sluggish resistance cell that was used for the general density indications, yet a gradient must have existed in order to maintain further diffusion of the fluid transported across the interface. Although the location of the outlet at the neutral level of the agitator tended to provide a first approximation to the mean density of the stratum, the fact that the point of true mean density was always at a somewhat lower elevation tended to make the diffusion rate computed from the density measurement slightly greater than that actually measured.

Under the circumstances, it may be concluded that eqs. (4) and (5) together describe the phenomenon under consideration with a reasonable degree of approximation. The more pertinent function represented by eq. (3) may hence be obtained from them by elinination of the quantity $T$, with the following result :

$$
\frac{\mathrm{V}}{\mathrm{F}^{5 / 2} \mathrm{R}}=5 \times 10^{4}
$$

For purposes of comparison with fig. 1, eq. (6) is plotted in fig. 7 in the form $F$ versus $R$ with $\mathrm{V}$ as parameter. At once evident is the fact that, as previously surmised, lines of constant relative diffusion are all similar functions of $F$ and $R$. But whereas the only line of constant diffusion appearing in fig. 1 was that for the limiting value of zero, it is just this limit that is nonexistent in fig. 7; and there is an appreciable difference between previous indications of the $3 / 2$ power and the present finding of the $5 / 2$ power in the functional relationship.

With regard to the latter disparity, only a power intermediate between these two can as yet be justified by simple reasoning. That is, the assumption that the rate of increase of poten- tial energy per unit volume, $v \Delta y$, is proportional to the rate of production of turbulent energy by the agitator, $p n^{3}$, will lead to the form $V \sim F^{2}$. (The effect of viscosity can be introduced only by a still more arbitrary assumption.)

As for the former disparity, the indication that a finite rate of mixing may be expected to prevail regardless of the magnitudes of the Froude and Reynolds numbers would be contrary to previous indications as well as to reason itself were it not for one very essential distinction. In the present experiments the state of turbulence was independently imposed upon the interface, whereas in the case of relative motion it varies with the intensity of shear between the strata. There is, however, a slight restriction upon the generality of this conclusion. The displacement of the point for the lowest Reynolds number in the inset of fig. 5 indicates that the function may approach a limit according to the broken curve, rather than continue indefinitely according to the straight line used as the basis of eq. (4). Although the existence of such a limit seems logical, it must be realized that an unwanted effect of viscosity was also present in the experiments to a variable degree : the decay of the turbulence with distance from the agitator, as a result of which the mixing coefficient at the level of the interface did not necessarily vary with the frequency alone as assumed. Allowance for this effect would only strengthen the conclusion that no limit of zero mixing was indicated by the experimental results.

Whatever the imperfections of the experiments herein described, they have disclosed two pertinent facts. First, turbulence generated in one of two fluid strata which are otherwise at rest neither penetrates the second stratum nor produces a buffer layer between the two; lather, lluid is entrained from the surface of the nonturbulent stratum and diffused throughout the turbulent zone. Second, so long as the turbulence is produced by some external mechanism, for small density differences a limit of stability comparable to that which characterizes interfacial shear is not to be expected; instead, there appears to be a finite rate of diffusion across the interface for any Froude and Reynolds numbers. Moreover, although the functional relationships derived from the experiments are linked quantitatively with the particular geometry of the apparatus, their form should nevertheless indicate the relative roles played by the Froude and Reynolds numbers no matter what the boundary proportions might be.

\section{REFERENCES}

[1] Engineering Hydranlics, edited by Rouse, New York, 1950 , p. 762.

[2] Engineering Hydraulics, p. 92. 